\title{
When is it democratic to postpone an election? \\ Elections during natural disasters, COVID-19 and emergency situations
}

\begin{abstract}
Holding regular elections are an essential feature of democratic practices. The case for postponing elections is often made during emergency situations, however. Despite the critical nature of the issue for democracy, peace and security, there has been sparse academic literature on election postponement. This article provides a new typology of reasons why elections might be delayed to disentangle the causal factors and normative rationale. It distinguishes the humanitarian case for temporary postponements during natural disasters. It then argues that substantive concepts of democracy and electoral integrity, rather than existing international/national laws and standards, should be used to inform decisions about postponement by relevant stakeholders, be it an electoral management body (EMB), government, parliament or the judiciary. The possible effects of natural disasters on electoral integrity are traced through a comparative analysis of past cases. The article holds that variations in context and the ability actors to strategically adapt to situations will make the effects contingent. Nonetheless, holding elections during natural disasters will often lead to severely compromised opportunities for deliberation, contestation, participation and election management quality. There is therefore strong, democratic case for time-limited postponement. However, the postponement will break institutional certainty, which could pose threats of democratic breakdown - especially in presidential systems. The best available safeguards for electoral integrity during natural disasters include the introduction or expansion of lowtech solutions such as early voting, strengthened risk management but also transparency and inclusivity in decision-making. Overall, there are important lessons for the broader scholarship and practice of democracy during emergency situations.
\end{abstract}

Key words: COVID-19, electoral integrity, election postponement, electoral management, election administration, democratisation.

Toby S. James

University of East Anglia

\&

Sead Alihodzic

International IDEA

Authors accepted version of a paper forthcoming in Election Law Journal. Please cite the final version. 


\section{Introduction}

One of the defining characteristics of a democracy is that it holds regular, periodic elections (Dahl 1971; Przeworski 1999). This requirement was famously enshrined into Article 21(3) of the Universal Declaration of Human Rights (UN General Assembly 1948). It is also embedded into many conceptualisations of electoral integrity (Norris 2014). At the same time, there are occasions where a natural disaster, such as an epidemic or tsunami may mean that holding an election will potentially introduce greater threats to human life and security. The problem was laid bare as the coronavirus pandemic spread in 2020. Between 21 February and 2 August 2020, at least 69 countries and territories across the globe decided to postpone forthcoming elections. And yet during the same time at least 19 countries decided to hold national or subnational elections as originally planned and in 9 countries those elections took place. Court case battles ensued elsewhere, with the Wisconsin Supreme Court blocking an executive order by the state governor to suspend in-person voting for the Presidential primaries in April 2020 (Supreme Court of Wisconsin 2020).

The question of whether elections should be delayed in such circumstances has rarely been given detailed analysis. It has arisen in rare court judgements, such as that in Wisconsin, where arguments have principally focussed on constitutionality. The question, however, is clearly critical for practitioners, judicial judgements and democratic theory as it raises much deeper arguments and is therefore a major gap in the broader democracy and electoral law literature.

This article firstly contributes to this literature by providing a new typology of reasons why elections might be delayed to disentangle the causal factors and normative rationale. Seven separate categories are set out which include those which are predominately postponed because of the political interests of the incumbent, but also those which are postponed for technical reasons, peaceful conciliation or humanitarian postponements that might be necessary because holding an election during a natural disaster would pose a threat to human life and health.

Secondly, the article contributes by making the case that the decision of whether to postpone or hold an election should be subject to assessment against broader democratic theory rather than international law and standards. The latter provide useful benchmarks, but there is no guarantee that these international laws and standards are democratic themselves - or best practice in rapidly changing situations. A substantive theory of democracy is used to identify five key principals of electoral integrity which are at risk when natural disasters hit.

Thirdly, the article makes the case that the effects of natural disasters on electoral integrity is unpredictable, not just because the nature of natural disasters and contexts will vary, but because actors have agency and can therefore strategically learn and adjust. 'Iron laws' about the effects of natural disasters on electoral integrity, may therefore not hold up. However, the article holds that there are major threats to opportunities for deliberation, contestation, participation and election management quality posed by natural disasters. The postponement paradox is that, however, postponing will break institutional certainty and this may lead to partisan scrobbling which could trigger democratic breakdown and undermine trust in the system - especially presidential systems that are used to fixed terms and states with low levels of political trust. We make specific recommendations about how elections could be conducted during natural disasters which are that low-tech solutions are used - but also that the process of deciding is as important than what decision.

The article will begin with a review of the very limited existing research that has been undertaken on the postponement of elections. It will distinguish the new concept of humanitarian postponements within a new typology of instances where scheduled elections might not take place or have been 
cancelled at any stage of the electoral cycle to disentangle the causal and normative reasons for this. Next, it will scrutinise the case for the humanitarian postponement of elections or electoral preparations in the face of looming or actual natural disasters which will threaten human life. It will then compare how holding or postponing an electoral event during emergency situations would affect the realisation of five key democratic principles: opportunities for deliberation, equality of participation, equality of contestation, electoral management quality and the institutionalisation of rules. Finally, the article outlines the measures that can be taken to protect electoral integrity during a natural disaster. Overall, this article has important consequences lessons for the broader scholarship and practice of democracy during emergency situations.

\section{The postponement of elections: what do we know?}

Although elections have been one of the most prominent areas of study in political science (Htun and Powell 2013), the elections that do not take place remain systematically understudied and undercategorised. There is some provision in international law and standards. Article 21(3) of the Universal Declaration of Human Rights notes that states must have regular, periodic elections (UN General Assembly 1948). Article 4 of the International Covenant on Civil and Political Rights, meanwhile, states that 'In time of public emergency which threatens the life of the nation and the existence of which is officially proclaimed, the States Parties ... may take measures derogating from their obligations under the present Covenant to the extent strictly required by the exigencies of the situation.' International electoral assistance agencies have issued guidance that any emergency provisions must be proportionate, non-discriminatory, temporary and limited in scope (Ellena and Shein 2020).

Political science research is much more limited, however. Datasets on electoral contests tend to measure the quality of electoral integrity or the opinions of voters in elections that have taken place (Hyde and Marinov 2012; Kelley 2011; Norris, Wynter, and Cameron 2018) and the drivers of electoral integrity within those events (Birch 2011; James 2020; Norris 2015) - rather than those elections which did not take place. We therefore know little about 'the dog that didn't bark in the night.' Elections that do not take place appear to be common, however. The NELDA dataset on elections lists 144 states that have had some previous experience of a 'suspended election' between 1945-2015 (Hyde and Marinov 2012). ${ }^{1}$ Examples cited in that dataset include civil wars such as the fighting between the ruling MPLA and the rebel UNITA in Angola or a military coup such as that under Pervez Musharraf as the Pakistani leader.

There has been a wider discussion about the timing of elections. This has considered issues such as the effects of early 'snap' elections, where it is constitutionally permissible to hold elections earlier than planned (Smith 2004). The timing of elections are also thought to be important with respect to post-conflict situations and democratic transitions (Alihodžić and Matatu 2019; Reilly 2002). Research on natural disasters and elections has considered the effects on vote share and turnout (Abney and Hill 1966; Flores and Smith 2013). There has been some discussion about the potential steps that election officials can take in the event of a natural disaster in the US, with Stein (2015) examining the conduct of the 2012 presidential election in the aftermath of Hurricane Sandy. Morley (2017) similarly considered how US states responded to natural disasters such as the 11 September attacks on New York City, Hurricane Katrina's destruction of New Orleans, and the constitutional cases that then followed. There have also been discussions of specific legal cases where courts have been asked to intervene to postpone an election, such as the 2013 California Gubernatorial Recall Election (Brady

\footnotetext{
${ }^{1}$ The cited variable is 'nelda1' - 'Were regular elections suspended before this election?'.
} 
2004). But once an election has been scheduled, should it take place come what may, or are there some circumstances where it should be delayed? There has been little critical examination of the case for postponing elections against democratic theory.

\section{Seven types of non-elections}

The motives and causes of not holding elections are varied and complex. It is important to distinguish these because non-elections are not just power-grabs by autocrats - the most intuitive reason for why an election might not take place. Table 1 therefore presents a new ideal-type typology of nonelections. The actors who cancel the election, their rationale and timing vary in each case. As an idealtype typology (Collier, Laporte, and Seawright 2008), cases may not always precisely fit into one single category and may have some aspects of each of them. However, the categories provide an important advance in identifying the variety of causes for postponing an election - which can help academics and judicial decision-makers determine whether or not they are power grabs and undermine democracy - or are actually necessary steps to reinforce democratic ideals.

Cancelled elections are those in which incumbents decide not to hold an electoral event as part of a deliberate statecraft power-grab. These cancellations can be long term or indefinite where, for example, power is seized through a military coup. There are numerous cases of elections being suspended for prolonged periods of military dictatorships, such as in Lesotho 1986-1993. Pervez Musharaff postponed the 2008 elections in Pakistan. However, they can also be short-term cancellations where leaders might be expecting that they will not be successful in a future contest. Some Venezuelan elections were postponed in 2016-18 as part of Nicolas Maduro's strategy to undermine opposition parties and their followers, or to buy time to mitigate negative popular opinion (Alarcon and Trak 2019, 126-27, 9-30).

Cancelled elections violate democratic norms, but there are a variety of other reasons why elections might not take place. Deep political crises such as those in FYR Macedonia (2012-16) can cause an institutional breakdown, preventing the taking place of scheduled elections (Alihodžić and Matatu 2019. Crisis postponements may therefore occur because there is a political stalemate and constitutional crisis. The causes of a non-election are therefore deeply political, but not a direct power-grab, and there is no indefinite cancellation of elections. Parliamentary elections in Egypt were postponed in $\mathbf{2 0 1 3}$ when an Administrative Court overrode a decree issued by President Mohamed Mursi calling the election. It also returned the electoral law, the subject of feuding between the opposition and Mursi's ruling Islamists, to the Constitutional Court for review, leaving Egypt 'in limbo' (Saleh 2013). Similarly, the Constitutional Court in Macedonia declared the dissolution of parliament unconstitutional in 2016, thereby cancelling the elections (OSCE/OHDIR 2016).

Transitional postponements are those where states determine that a broader constitutional framework needs to be established before general elections are held. Both Nepal and Tunisia decided to adopt new democratic constitutions before conducting general elections. To do so, they held Constitutional Assembly elections Nepal 2008, Tunisia 2011. The 2007 Constitutional Assembly elections had to be postponed in Nepal due to the absence of a necessary legislative framework (Pokharel and Rana 2019). The motives of actors in transitional postponements are therefore about deepening democratic institutions rather than a power-grab, and the constitutional reforms being put in place should involve a clear framework for the holding of elections.

Technical delays might also be needed. Elections are huge, complex logistical events which require a vast volume of resources, laws and staff (James 2020). It might therefore be necessary to delay parts of the electoral process until staff training has been completed, robust ICT systems have been 
established or electoral registers have been compiled. The Nigerian 2019 Presidential and national assembly elections were postponed by the Independent National Electoral Commission, three days before the scheduled elections ' $f$ ] ollowing a careful review of the implementation of the logistics and operational plan' (Mckenzie, Swails, and Smith-Spark 2019). The decision was announced only five hours before polls were due to open and election put back a week. Delays can be longer. The Bosnian post-war elections in 1996 were postponed for three months due to technical delays. The 1991 census was to be used as the electoral register - but there were mistakes scanning the data. Meanwhile, voter identification was hampered by the problem of issuing documents to internally displaced refugees (Hadziabdic 2019).

Elections might be postponed when there is the death of a candidate. This situation has been described as 'quite common in local elections' (Rallings and Thrasher 1997, 44). This is especially problematic where the candidate is individually listed on the ballot paper rather than being a candidate through a party-list system. The procedures for postponement or other steps are usually set out in national laws and may depend on the timing of the death with respect to the electoral cycle and the affiliation of the candidate (ACE 2020). In the United Kingdom, if an independent candidate dies ahead of a parliamentary election then the election continues and is only rerun if the deceased candidate receives the most votes. ${ }^{2}$ If the candidate is representing a political party, however, then the election is halted immediately and a new election is called (Electoral Commission 2019, 33). By contrast, in the Republic of Ireland, voting was delayed across the Tipperary constituency in the 2020 general election when an independent candidate died five days ahead of the polls (Holland 2020). The democratic rationale for postponement is a concern that voter choice would be adversely affected if a political party is unrepresented on the ballot paper and parties will be unequally able to contest the election.

An outlier are annulled elections, which are polling events that do take place as scheduled, but which subsequently have their result overridden. This might be by a constitutional court who might judge that the election was not constitutional for technical reasons, or because there was evidence of widespread electoral fraud (Vickery, Ennis, and Ellena 2018). For example, the result of the 2019 Malawi Presidential election was annulled by the Constitutional Court after it ruled that 'anomalies and irregularities have been so widespread, systematic and grave such that the integrity of the result was seriously compromised, and can't be trusted as the will of voters' (Reuters 2020). The 2017 Kenyan presidential elections were annulled after the Supreme Court said that the polls were 'neither transparent nor verifiable', blaming the country's electoral commission for the shortcomings (Burke 2017). Annulled elections are an outlier in so far as the electoral event did take place and the cancellation is post-election. They therefore feature last in the typology. However, we include them because they are like other categories in that they are electoral contests which are scheduled but which do not have their results verified.

We can also distinguish humanitarian postponements where elections might not take place because of threats to human life, which are considered in more detail next.

\begin{tabular}{|l|l|l|l|}
\hline & Stopped by whom? & Why? & When? \\
\hline Cancellations & $\begin{array}{l}\text { Incumbent } \\
\text { Military }\end{array}$ & Power-grab & Pre-election \\
\hline Crisis postponements & $\begin{array}{l}\text { Incumbent } \\
\text { Opposition }\end{array}$ & $\begin{array}{l}\text { Political stalemate } \\
\text { Constitutional crisis } \\
\text { Violence }\end{array}$ & Pre-election \\
\hline
\end{tabular}

\footnotetext{
${ }^{2}$ In this case, the non-election also falls onto the category of annulled elections (see below).
} 


\begin{tabular}{|l|l|l|l|}
\hline $\begin{array}{l}\text { Transition } \\
\text { postponements }\end{array}$ & $\begin{array}{l}\text { Transitional } \\
\text { government }\end{array}$ & Democratic reforms & Pre-election \\
\hline Technical delay & $\begin{array}{l}\text { EMB } \\
\text { Incumbent }\end{array}$ & $\begin{array}{l}\text { Technical issues } \\
\text { Violence }\end{array}$ & Pre-election \\
\hline Candidate death & $\begin{array}{l}\text { EMB } \\
\text { Incumbent }\end{array}$ & $\begin{array}{l}\text { Equality of } \\
\text { contestation and voter } \\
\text { choice }\end{array}$ & Pre-election \\
\hline $\begin{array}{l}\text { Humanitarian } \\
\text { postponement }\end{array}$ & $\begin{array}{l}\text { Incumbent } \\
\text { EMB }\end{array}$ & $\begin{array}{l}\text { Emergency situation } \\
\text { threatening life }\end{array}$ & Pre-election \\
\hline Annulled & $\begin{array}{l}\text { Judiciary } \\
\text { Incumbent } \\
\text { Military }\end{array}$ & $\begin{array}{l}\text { Not constitutional } \\
\text { Power-grab } \\
\text { Not implementable }\end{array}$ & Post-election \\
\hline
\end{tabular}

Table 1: A typology of delayed elections

\section{The humanitarian case for delaying elections}

The loss of life during electoral events as a result of electoral violence has seen considerable academic attention. This is usually seen through the lens of deliberate attempts to suppress the opposition vote or wreck the electoral process as part of a campaign to undermine the legitimacy of the government or democratic process (Birch, Daxecker, and Höglund 2020; Höglund 2009). There has been much less focus on the loss of life that can occur where no deliberate perpetrators were involved. There is enormous scope for this to occur, however. The National Electoral Commission (KPU) of Indonesia reported that over 300 poll workers died as a result of fatigue-related illnesses following the 2019 elections (Manafe and Yasmin 2019) for example.

There is an obvious humanitarian case for delaying the conduct of elections where it might bring about immediate threats to human life and security. Electoral democracy is a political system which is valued for bringing about democratic ideals - but it is also valued for bringing greater material well-being to citizens (Sen 1999b). Holding elections when they might jeopardise lives would therefore be a counter-intuitive use of institutions designed to facilitate individual and collective preservation.

There are a variety of scenarios in which the loss of life might occur during the electoral process which were not the result of deliberate action. Natural accidents are major adverse physical events, resulting from natural processes of the Earth. They include earthquakes, tsunamis, wildfires, epidemics and pandemics (Table 2). There are many examples worldwide of when holding elections during such unexpected events would have threatened human life. The 2019 local elections in Papua New Guinea were forced to be postponed because of an eruption of Mount Ulawun, forcing thousands of people to be displaced (RNZ 2019). Haiti's electoral plans were devasted in 2020 by an earthquake (Zengerle and Guyler Delva 2010). Heavy rains from Cyclone Idai killed more than 750 people and forced the National Electoral Commission to postpone the electoral census in Mozambique (Machel 2019). Climate change forecasts estimate that some of these problems might become more frequent.

One prominent example of a pandemic was the spread of COVID-19 in 2020. A pneumonia with an unknown cause was detected in Wuhan, China and first reported to the World Health Organisation Country Office in China on 31 December 2019. The outbreak was declared a Public Health Emergency of International Concern on 30 January 2020. Cases were rapidly reported around the world and it was declared a pandemic by the World Health Organisation on 11 March 2020 (WHO 2020b). Between 21 February and 2 August 2020, at least 69 countries and territories across the globe decided to postpone forthcoming elections (International IDEA 2020a). Elections that have previously been postponed for public health reasons include those in light of the Ebola crisis in West Africa (20132016), such as the 2016 Presidential election in the Democratic Republic of Congo, and the 2014 
senatorial elections in Liberia (Mark 2014). Meanwhile, during the 2009 epidemics of Swine Flu (H1N1) virus in Mexico, campaign restrictions were put in place such as discouraging political rallies of more than 40 people, urging candidates not to wear neckties( as they were suspected to be potential carriers of viruses), and discouraging kissing (including baby kissing) and handshaking (Lacey and Malkin 2009).

There are major risks of casualties throughout the electoral cycle during a natural disaster because it involves the rapid movement and concentration of people within a country and between countries. The compilation of the electoral register often requires the posting of registers outside of polling stations so that citizens and parties can inspect them and residential properties to be door knocked to check the accuracy and completeness of the register. The campaign stage of elections involves holding major rallies and political parties reaching out to voters via the canvassing of properties. Election day itself can involve the movement of millions of citizens. Many countries do not provide external voting opportunities and so citizens must travel from overseas in order to vote (Hartmann 2015). Voting involves staffing thousands of polling stations with poll workers - who are often retired and elderly (Clark and James 2017). Counts often take place in crowded areas such as halls or within polling stations where social distancing is difficult with many people present. Touch screen equipment, or sharing pens to mark ballot or to sign voter register, are opportunities for the transmission of infectious diseases.

Natural disasters can be distinguished from technological disasters, which are human-made and occur in or close to human settlements (Table 2). Industrial, transport, and other accidents such as rail crashes and explosions which are accidental may justify a humanitarian postponement of part of the electoral process. A technological failure such as power outages can cause major problems to the electoral process now that technology is often central to the electoral process through e-counting and electronic poll-books, for example (Loeber 2020). Some technological disasters, whose causes are more complex in nature, might not justify humanitarian postponement. Famines can be caused by crop failure owing to environmental conditions - but they are usually also at least partially caused by human failure to prevent famine and weak accountability systems (Devereux 2009). They will therefore not usually justify humanitarian postponements. Famines were famously thought by Amartya Sen $(1999 a, 178)$ to be prevented by the holding of elections. But at their peak, unexpected famines could place humanitarian strains as state resources address human health and leave public services undeliverable. External wars, civil wars and violence can create situations in which human life would be at threat by an election, but they are best diagnosed as crisis postponements.

\begin{tabular}{|l|l|}
\hline Scenario & Examples \\
\hline Natural hazards & Geophysical (earthquakes, landslides, tsunamis, volcanic activity) \\
& Hydrological (flood, landslide, wave action) \\
& Climatological (drought, wildfire) \\
& Meteorological (cyclones, storms) \\
& Biological (epidemic, pandemic, insect/animal plagues) \\
& Extra-terrestrial (space weather, meteoroids) \\
\hline Technological or & Conflicts \\
man-made hazards & Famines \\
& Displaced populations \\
& Industrial accident \\
& Transport accident \\
& Miscellaneous accident (collapse, explosion) \\
& Technological failure \\
\hline
\end{tabular}

Table 2: Examples of emergency situations, source, authors, based on: CRED (2020) 
The humanitarian case for postponing elections is also strictly time-limited to that necessary to make elections deliverable, otherwise there are perverse incentives for leaders to exacerbate an emergency to deliberately postpone an election. A protracted emergency would usually give an opportunity for electoral officials to put in place alternative election arrangements. The US outbreak of COVID-19 in early 2000, gave sufficient opportunity for postal voting mechanisms to be in place for the November 2020 US Presidential election, for example (Persily and Stewart III 2020), although there were clear legal and political challenges. Emergencies are sometimes anticipatable. Floods and hurricanes are more likely in some regions than others. Risk assessment and contingency plans can therefore be developed. A late postponement, following a failure to take reasonable action to prepare for an election given a known threat, is therefore closer to a cancelled election if there are also partisan motives at play.

\section{Democratic theory in practice}

Although there might be humanitarian reasons for postponing an election, the prospect of not holding an election when one is scheduled is, at first glance, contrary to democratic ideals. To assess whether postponing elections is in line with democracy and electoral integrity requires definitions of these concepts. If a procedural definition of democracy and electoral integrity is used, which define the concepts in terms of whether a particular set of institutional practices are in place (e.g. Dahl 1971; Przeworski 1999), then it is possible that any postponement will be considered anti-democratic. As David Beetham argues, the weakness of procedural definitions, however, are that they provide no rationale for why these institutions should be considered 'democratic', in the first place, rather than, say, "liberal", "pluralist", "polyachric" or whatever other term we choose' (Beetham 1994, 26). International law may or may not allow the postponement of elections - but does that make this just and democratic?

Democracy, based on the work of David Beetham (1994), is here considered as a system that achieves political equality and popular control of government (also see: Beetham et al. 2008; International IDEA 2019). This is a substantive theory of democracy that considers whether key principles have been achieved, rather than a checklist of procedures. We define electoral integrity as the realisation of principles in the conduct of election that are necessary to support the broader realisation of democratic ideals. Building from Garnett and James (2020) these would include, but are not limited to: opportunities for deliberation, equality of participation, equality of contestation, electoral management quality and the institutionalisation of rules.

This article now seeks to map some of the underlying causal mechanisms for how natural disasters can shape electoral integrity. This enables the democratic dangers and advantages of election postponement/continuation to be identified. Our argument is that context is important because the prior legal, organisational, economic and political relationships will vary. Key actors such as incumbents, political parties and electoral management bodies also have some creative agency and may strategically learn to identify and adopt different strategies. Accurate prediction of the effects of natural disasters on electoral integrity may not entirely be possible, but we can better understand how the strategic context will change. This position draws from a realist sociological approach, as set out by James (2020,18-30). The realist sociological approach conceptualises causation as contextually contingent and partially dependent on the reflective agency. The aim is therefore to identify causal mechanisms through past empirical studies, examples and cases (Pawson et al. 2005).

\section{Opportunities for deliberation}

One principle is the importance of opportunities for deliberation. Citizens need, as Dahl put it, full opportunities to formulate their preferences (Dahl 1971, 2-3). This meant freedom to form and join 
organisations, freedom of expression, the right to vote, the right to compete for public office and alternative forms of information. Deliberation requires freedom from explicit and implicit voter intimidation so that citizens feel that they can speak freely (Birch and Muchlinski 2018; Schneider and Carroll 2020). Less minimalist approaches to democracy place a more demanding expectation on the electoral process. Deliberative democracy theorists point to the importance of societies discussing and debating political issues rather than simply aggregating interests. Conflicts can be dissolved and better decisions can be reached through deeper argumentation, dialogue and reflection. Deliberative theorists claim that there would be a democratic deficit if the entirety of citizens' engagement in the political process is at the ballot box and encourage both micro-level deliberative forums and system level deliberation (Gutmann and Thompson 2009; Mansbridge and Parkinson 2012). However, deliberation during the electoral process, not least the electoral campaign, remains a critical window for this to happen. Deliberation during the electoral campaign is therefore important. Good deliberation, argues James Fishkin (2011, 84-5) requires good quality information, substantive balance, a diversity of viewpoints, conscientiousness and equal consideration of the arguments.

Deliberation within the electoral campaign is often not achieved in 'normal' times. Simply holding elections is insufficient since there is no guarantee that citizens will actively consider their interests and the issues - or that they will vote. There are therefore often concerns that "zombie" like elections could be held characterised by apathy and disengagement (Koch 2017). Emergencies can, however, fundamentally undermine opportunities for deliberation since they depend on information and news content from independent journalists. Media outlets might be reduced to minimal services to minimise risks to human life during a natural disaster - or they could become entirely dysfunctional. The 2015 Nepal earthquake caused the destruction of newsrooms, partial destruction of communications infrastructures, major damage to transport networks. As a result, journalism practices were heavily affected with news production, gathering were heavily constrained and journalistic rigour was affected (Sreedharan, Thorsen, and Sharma 2019). Campaigning can become restricted during emergency situations. Many countries imposed 'lockdowns' during the 2020 COVID19 epidemic to prevent mass gatherings and citizens leaving their house. In these circumstances, opportunities for campaigning become much more limited. Individual citizens may also find themselves in conversation with a smaller pool of people, if any, outside of their household - giving them access to a smaller pool of everyday conversations. The nature of argumentation can become more emotive and less rational during natural disaters, both online and in how politicians repond to each other (Al-Saggaf and Simmons 2015). During the 2009 Swine Flu epidemic, Mexico saw heated clashes over the 'politicisation of the epidemic' (Al-Saggaf and Simmons 2015).

Some electoral events can continue during natural disasters - depending on the nature of the disaster. TV debates can take place during pandemics without an audience, for example, as they did between Joe Biden and Bernie Sanders in March 2020 during the COVID-19 pandemic =, in competition to be Democratic candidate for the US Presidency. Some commentators argued that the absence of an audience enabled the discussion to be more substantive in focus, with fewer crowd-pleasing punchlines looking for applause (Grynbaum 2020). There were also innovative 'virtual rallies' during the pandemic. Home Minister Amit Shah, of the incumbent Indian BJP, held a rally in June 2020 ahead of the Bihar legislative elections which was viewed by 3.9 million people over the internet (PTI 2020). At least 15,000 LED screens and 70,000 smart TVs were also installed across West Bengal by the governing party to enable citizens to watch the event (Tribune 2020), at a reported cost of Rs 100 crore (NDTV 2020). The online rally was not deliberative in nature, however, as it focussed on the achievements of the Modi governments and was accompanied with applause from BJP employees from the party HQ in Delhi.

Holding an election during an emergency situation is also likely to alter the policy agenda considerably. The public debate may become centered on the 'focusing events' of the crisis and the incumbent government's management of this. Discursive debates and voter intensions may come to be set by 
this single issue. There is strong evidence that natural disasters do change voter preferences as the management of the crisis becomes the salient issue rather than other subjects. This might be a lifeline for those who manage crises well but have a poor record on other issues during the mandate, and vice versa. Voters in India over the period 1977-1999 have been shown to have punished the incumbent party for weather events beyond its control, but also reward the government for responding well to disasters (Cole, Healy, and Werker 2012). Supporting evidence for voter preferences changing because of a natural disaster has also been found in Croatia and the USA (Bovan, Banai, and Banai 2018).

\section{Equality of contestation}

Elections should have a level playing field for candidates. There is often some degree of structural advantages for parties and candidates, since they will enter the campaign period with a greater concentration of resources if they are backed by wealthy donors, meanwhile incumbents might have access to state resources such as editorial influence over the state media outlets (Norris and van Es 2016).

Emergencies can, however, exacerbate some of these tensions. In states where incumbents have control over the state media they may be able to continue to use this important campaign tool, with opposition parties remain unable to mobilise if they are restricted by 'lockdowns' or weak communications infrastructures. Polish President Andrzej Duda made television appearances at border checkpoints, hospitals, food bank and new production lines of hand sanitizer during the early campaign of the 2020 Presidential election, while opposition parties were unable to canvass, and Duda's poll rating rose in the meantime because of COVID019 restrictions (Strzelecki 2020).

Emergency situations can also bring massive inflows of revenue in the form of donations and humanitarian aid, which increases the cash and resources available for buying votes. There is evidence that this occurred during the rainy season of 2010-2011 in Colombia, and the subsequent 2011 local elections (Gallego 2018). The allocation of EMA hurricane disaster aid awards in Florida has been shown to have had a positive turnout effect on Republican voters in the November 2004 election, but a negative effect on Democratic opposition turnout (Chen 2013). Inter-organisational blame games may also open up that can be exploited. In the US, it has been shown that if the president rejects requests by governors for federal assistance, the president is punished and the governor is rewarded at the polls (Gasper and Reeves 2011).

Postponement can pose alternative threats to equality of contestation, however. Postponement can place additional pressures on independent candidates who may lack the resources that established political parties have. The decision to postpone the London Mayoral election of 2020 to 2021, led to a prominent independent candidate withdrawing, claiming that it would be difficult to continue the campaign for another whole year without sufficient resources (Lydall 2020).

The setting of a new revised date also provides the opportunity for elite statecraft, as incumbents seek to set a schedule that would boost their chances of electoral success. Elections in Montenegro and Croatia were postponed in early 2000 in response to the COVID-19 crisis. Incumbents were thought to be timing the new electoral event so that it would fall on the back of a bounce for the management of the crisis, but before a post-COVID recession took place. Montenegro President Milo Djukanovic, for example, was reported to be considering a snap poll in the summer of 2020, rather than one in the Autumn which might see an economic dip because of the dependency on the struggling tourism sector (Vladisavljevic et al. 2020). It is therefore notable that elections can be both put back and brought forward as a result of a natural disaster.

The effects of natural disasters on equality of contestation can also vary across political systems. Flores and Smith (2013) report that in large coalition systems, often described as democracies, disasters have 
little effect on levels of protest or leader survival. But the electoral prospects can be shaped by the number of falities. Meanwhile, in more autocratic systems, disasters can increase protest and reduces leadership survival. They argue that disasters can concentrate displaced people, which makes it easier for them to mobilse and protest against the government. It can also reduce the state's repressive capacity.

\section{Equality of participation}

A third principle that should underpin elections is equality of participation. Democratic elections, at their best, are characterised by the high turnout and equal levels of participation across different groups in a society. Without this, the result of an election may be shaped by some groups more than others. Historically, many polities often have deep inequality in levels of participation across social and economic groups (Fraga 2018). This is a major threat to political equality within a polity because these uneven levels of participation are often partially driven by uneven access to resources and external factors (James and Garnett 2020).

There is nuanced evidence that turnout is likely to be lower than it might otherwise be during natural disasters. Floods in Calgary in 2016 were not thought by Bodet et al. (2016) to have affected turnout, when flood-affected areas were compared with those which were not. However, other studies point to more nuanced effects. Examing the 2006 mayoral election in New Orleans following Hurrican Katrina, Sinclair et al. (2011) show that living in flood-affected areas did affect voting. Their rationale was cost-based: those who were more likely to be displaced, possibly now having to temporarily live outside New Orleans would need to take extraordinary steps to vote. They were indeed found to be less likely to vote. However, there were other dynamics. Those who were severely flooded, having experienced more than $6 \mathrm{ft}$ of flooding were more likely to participate in the election than those who experienced less flooding. This was attributed towards state efforts to make voting more accessible for these disadvantaged groups. It was also attributed to motivational factors: those who are deeply affected by natural disasters may become more civic-minded after the event.

Many of the elections that were held during the spread of COVID-19 in 2020 saw turnout drops. Figure 1 summarises the change in turnout against the previous election for countries that held national elections during the pandemic. The figure covers elections held between 1 January and 19 July 2020 and only includes those countries where there were reported cases of COVID-19. The accumulated number of cases by election day are indicated in brackets using data from the World Health Organisation. The mean change in turnout was -6.21 percentage points. The greatest fall was in Syria, which the government attributed to citizen's concerns about coronavirus (al-Jazaeri 2020), but there were also broad electoral integrity concerns (Ibrahim 2020). Guinea saw a major decline, but there was an opposition boycott of the election (Fofana and Philipps 2020). Turnout in the Iranian parliamentary elections hit a rock-bottom 42.3 per cent during the COVID-19 pandemic, the lowest since the 1979 revolution. Iran's Supreme Leader Ayatollah Ali Khamenei blamed the low turnout on the 'negative propaganda' about Coronavirus (Al Jazeera 2020). Media sources reported that Coronavirus was discouraging citizens to vote in Mali, which announced its first coronavirus death, just hours before the polls opened (Mules 2020). There was also some significant falls in local elections. The first round of French elections saw turnout drop to 44.7 percent, a record low, and substantially lower than the last contests in 2014 of 63.6 per cent. After the polls closed, the French Prime Minister admitted that the "high abstention rate shows the increasing concern of our citizens in the face of the epidemic we are up against' (Momtaz, Braun, and Kayali 2020). The Burundi election saw much higher turnout, but it was the first 'competitive' election with the incumbent standing down (Burke 2020). Extensive special measures were put in place in Korea (see below). 


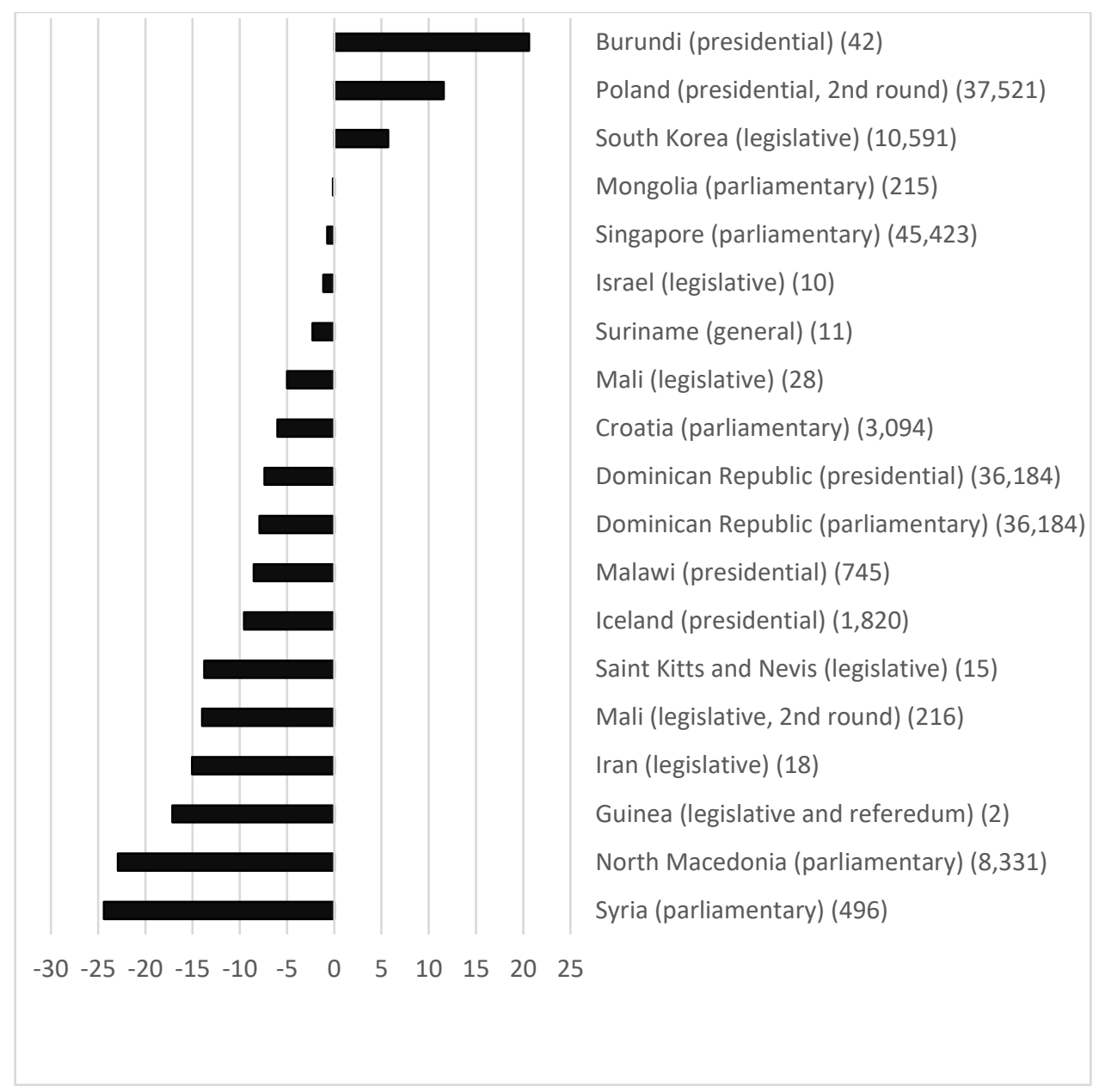

Figure 1: Change in turnout in national elections held during January-June 2020 compared to the previous election. Source: authors, using data from International IDEA (2020b) and the World Health Organisation WHO (2020a). Voter age population turnout used.

The United States had its first reported case of local transmission on 26 February 2020 (Schumaker 2020). Figure 2 presents the change in turnout in the primaries held between 1 March and 9 June 2020, against 2016 turnout levels, where turnout data was available from the United States Elections Project. The number of reported COVID cases in each state on election day is in brackets, followed by the election date. There was an mean fall in these contests was 1.61 percentage points. There were falls across March with a more mixed picture in June. Attributing change in turnout level to Coronavirus in the primaries is difficult because the nature of the contests differed to 2016. Bernie Sanders dropped out of the Democratic race on 8 April, establishing Joseph R. Biden Jr. as the presumptive nominee and making the presential primaries less important. In 2016 Hiliary Clinton was not nominated as the presumptive nominee until 6 June. However, there were also local contests that would have been important in sustaining interest in some states. Mitigating strategies, such as the expansion of postal voting was also put in place by May with states such as Wyoming, Hawaii, Nebraska, Kansas, Ohio, Alaska and Oregon voting by mail (Corasaniti and Saul 2020). 


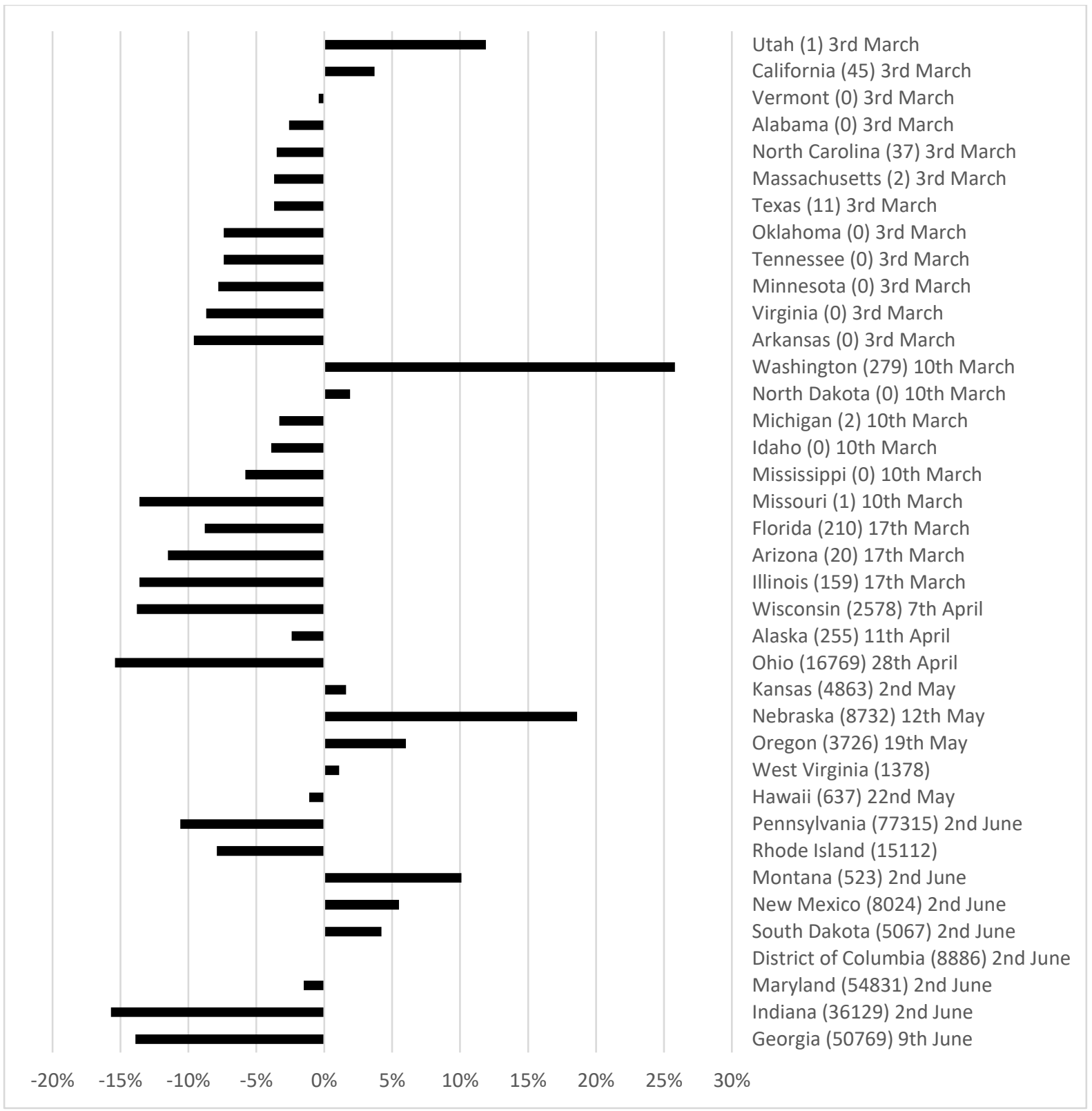

Figure 2: Change in turnout in US Primaries between 2020 and 2016. Source: authors using data from the United States Election Project (McDonald 2020) and the New York Times (2020).

The threat to voters posed by an epidemic is different in nature to a flood. The logic behind these declines are likely to include citizens not wishing to risk their physical health and the health of their family members. Holding elections in such circumstances therefore means that turnout is likely to be much lower than it might otherwise be. In the midst of a presidential election year, about two-thirds of US citizens (66\%) said that they wouldn't feel comfortable going to a polling place to vote (Horowitz, Igielnik, and Arditi 2020,4). However, the situation is further complicated if turnout is likely to disproportionately decline amongst certain groups. COVID-19, for example, was reported by the WHO be more dangerous for older people and those with underlying health conditions (WHO 2019). UK studies also found that the risk of dying from COVID-19 was higher amongst Black, Asian and Minority Ethnic (BAME) groups than in White ethnic groups (Public Health England 2020a, 2020b). It is therefore possible that these citizens might be especially less likely to vote than other citizens. Given that citizens that have physical disabilities are likely to vote, this would sharpen an underlying inequality in the electoral process (Johnson and Powell 2020), likewise for minority ethnic groups. Ironically, older voters are usually those more likely to vote. Holding elections when specific groups are more likely to 
have their health at risk would clearly mean that appropriate strategies would need to be put in place by electoral authorities process. James and Garnett $(2020,117)$ define inclusive voting practices as 'policy instruments which reduce inequality in the electoral process for citizens, including, but not limited to the voter turnout and registration gap'.

\section{Electoral management delivery}

A fourth principle is robust electoral management quality. Electoral laws can be designed in ways which support and strengthen democracy, but like all public policies, they require successful implementation on the ground. Convenience, quality of service, transparency, professionalism, probity, cost-effectiveness, citizen and stakeholder satisfaction are all hallmarks of good equality election delivery, just as they are for other public services (James 2020,66).

Emergencies can, however, pose major logistical problems which could force elections into major compromises, or even make them undeliverable. The delivery of elections are reliant on huge workforces in order to deliver an election (James 2019), which may suddenly not be available. Many countries rely on a temporary workforce close to election day to serve as poll workers, presiding officers and poll clerks. The hours that they work can be very lengthy and issues with the recruitment of these workers is often commonly reported even in 'normal' times (Burden and Milyo 2015). In the UK, for example, the poll worker labour force is made up of mostly women (63\%) with an average age of 53 and they are very often retired. In some countries serving as a poll worker is a compulsory civic duty, so there might be a more evenly distributed demographic of staff (Clark and James 2017). A natural disaster could suddenly pose recruitment and absenteeism problems threatening the delivery of the election. The 2020 Chicago Primary elections were held while President Trump advised Americans to avoid groups of 10 or more. "The city is just understaffed," one election official said and citizens went to the polls (CBS Chicago 2020). Poll worker recruitment problems were also reported in the much-criticised Georgia primary (Thanawala 2020).

The postponement of elections will bring financial challenges for the electoral management body These could include the sunk costs involved in preparing for the election such as staff and the hire of premises which might not be refundable. Should they be refundable, then there is an ethical question for electoral management bodies because claiming refunds might have a knock on consequences for others who might already be experiencing financial hardship. In the event of postponement there might be future challenges involved in securing sufficient funds to run the election. Public sector finances are likely to be stretched because of increased spending on healthcare business support packages, or other wider response to the emergency. The Mongolian President proposed postponing parliamentary elections in 2020 to divert resources to COVID-19 (Xinhua 2020).

Postponements can then also lead to a future backlog of electoral contests. Elections may need to be held the following year, perhaps concurrent to elections of other types of elections. The postponement of the English local elections in $\mathbf{2 0 2 0}$ meant that they would be simultaneously be held in 2021 alongside 'a bumper set of polls' including those for the Scottish and Welsh parliaments, English councils, police and crime commissioners, London mayor, London assembly, regional mayors and local mayors (Clark 2020). Many of these have different legal frameworks and electoral systems which poses a threat of confusion for citizens, and implementation challenges for administrators. When different types of elections are run simultaneously, problems are more likely to occur (Clark 2017).

Supply chains are also likely to be affected. The rapid outbreak of COVID-19 meant that there were global shortages of personal protection equipment for medical staff, as well as ventilators. Lockdowns also affected the transportation industry which meant the slower delivery of food and other supplies. 
In these circumstances, the supply of other essential items for an election will suddenly become difficult. Electoral officials in Chicago reported that equipment was not delivered on time for their primary elections (CBS Chicago 2020).

\section{Institutionalisation}

A fifth principle is that constitutional rules surrounding elections should provide institutional certainty and clarity about the rules of the game. The scheduling of elections provides such institutional certainty that a contest will take place. This incentivises rivals to challenge the incumbent through the ballot box rather than through violence or other means. The certainty of holding an election encourages trust amongst citizens in the system because they come to believe that there will be an opportunity to remove the incumbent from office.

Natural disasters can, however, undermine much of this. It will immediately create uncertainty about whether an election is deliverable as scheduled. Proposals for postponement will immediately unpick the certainty of electoral rules, especially in presidential systems of government that are characterised by strict fixed-terms of office. The removal or relaxation of institutional certainty creates opportune statecraft moments for incumbents, who might often cite Article 4 of the International Covenant on Civil and Political Rights in support of their case for postponement. They are likely to be able to set the timetable for the new election that is favourable in terms of shifts in opinion polls. They could postpone elections indefinitely and claim a prolonged mandate. Hungarian prime minister, Viktor Orban saw legislation through parliament which had the aim of 'strengthening and extending the decrees issued during the state of emergency and give the government authorisation to issue decrees for an indefinite term as long as the state of emergency is in effect'. This included provisions that no local or national elections or referendums could be held until the end of the state of emergency. An international outcry followed and claims were made that Coronavirus had killed its first democracy. The opposition pressed for a 90-day deadline for the emergency provisions claiming that if it is 'justified to empower Viktor Orbán to govern by decrees until the end of his life...we call that a kingdom' (Zoltán 2020).

Even where power-politics tactics are not being played, the sudden uncertainty in the electoral timetable might erode trust amongst rivals and citizens. Accusations from oppositions that incumbents are postponing for partisan reasons will undermine legitimacy within the electoral process, and citizens often take cues from candidates and parties (Vonnahme and Miller 2013). Politicians have an important gate-keeper role in fostering trust in the system (Levitsky and Ziblatt 2018), but might be inclined to 'points score' against incumbents.

When the decision to postpone the election during a natural disaster yields powers that translate to political and electoral advantages of the incumbent, then the election would fit into the 'cancelled elections' category of our typology in Table 1. However, when the postponement does not diminish political opportunities for other political actors - and possibly even opens space for more solidarity and unity - then it would fit more neatly into the humanitarian postponement category.

\section{Counteracting the effects of natural disasters}

What policy instruments could be introduced to still hold an election during or immediately after a natural disaster? One obvious strategy would include the introduction of early voting, if this is not available, whereby citizens can cast their ballot over several days. 'Voter traffic' can then be spread over out rather bunched into one day. This would help to establish social distancing during an epidemic, but would also even out the demand on depleted services following events such as earthquakes and floods. In the April 2020 South Korean parliamentary election provisions were made to encourage early voter turnout so that polling stations were not too busy on polling day, and a record 26.7 per cent of voters voted early (Spinelli 2020). Early voting would require further resourcing 
because of the cost of additional staff and hire of premises and the capacity of the state to deliver this might not be available. However, it is a 'low-tech' solution that could often be easily upscaled.

There are also opportunities for extending the provision of remote voting mechanisms where they are not already in place, or scaling them up where it already exists. Internet voting remains relatively untested and there are increased concerns about cyber-security. Introducing it at short notice is also impractical (Krimmer, Duenas-Cid, and Krivonosova 2020). However, all-postal elections have been held in many jurisdictions in the past (Killer and Stiller 2019). In Bavaria, Germany, all-postal voting mechanisms were therefore introduced during the COVID-19 crisis which completely excluded inperson voting in order to mitigate health risks of contagion posed through close contact (Schwarz 2020). As noted above, postal voting was expanded in the US primaries. Remote voting does involve trade-offs, which could undermine other aspects of the electoral process in some contexts. Ballot secrecy could be undermined (Elklit and Maley 2019). There have also been concerns about postal voting and electoral fraud (Wilks-Heeg 2008), with specific communities often claimed to be more vulnerable to undue influence (Hill et al. 2017). However, in comparison to holding no election, this could be an important inclusive voting practice to keep the electoral show on the road, especially given that cases of electoral fraud are often low, at least in strong democracies.

There is also a danger, however, in introducing postal voting where electoral administrators have no prior experience of this. Postal voting has often been trialled before being implemented more widely (James 2011) to enable systems to be tested and new procedures to be learnt. The late adoption of new practices is therefore likely to put considerable strain on electoral officials and threaten electoral management quality. Last-minute changes to electoral law can also threaten legal certainty and therefore institutionalisation. Electoral officials can be left with inadequate preparation time to adjust election materials and training staff. There might be a perception amongst voters that lastminute amendments have been introduced to favour one party over others. The Council of Europe has therefore previously set out that electoral rules should not be open to amendment less than one year before an election (Venice Commission 2002, 10). States that have rushed to implement postal voting have often hit logistical problems. For example, legislation was proposed in Parliament to hold the 2020 Polish Presidential election entirely by postal ballot rather than postpone during the COVID19 pandemic. Major concerns were raised by OSCE/OHDIR, however, that these last minute changes would threaten the stability of electoral legisaltion and legal certainty (OSCE/OHDIR 2020). In eventuality, the election had to be postponed only hours before the poll. Postal voting would also be difficult to implement in areas where the postal service infrastructure has been hit by the natural disaster, or where it was already of poor quality.

Further policy instruments specific to a pandemic include the provision of personal protection equipment, as was undertaken in South Korea during the legislative election of April 2020. Safeguards introduced into polling stations under a Code of Conduct for Voters included requirements to wear facemasks while queuing, the provision of hand sanitizers and gloves to votes and temperature checks - with citizens showing signs of ill-health then being re-directed to special polling stations with even higher degrees of protection. Turnout in South Korea rose by 8.2 per cent against the previous legislative election in 2016 (Spinelli 2020). The capacity of the South Korean state, however, is not replicable worldwide. The introduction of some these provisions would therefore be difficult in other circumstances.

\section{Conclusions: the postponement paradox}

Elections are at the bedrock of the democratic process. They are indispensable for bringing rule by citizens as opposed to narrow political or sectional elites. There are often calls for them to be postponed during emergency situations and natural disasters, but there has been very little academic attention on this issue. Most research has instead focused on the integrity of the elections that do take place. The elections they do not take place have a crucial importance if we are to understand 
democracy, democratisation and electoral integrity, however. This article has therefore set out a new typology of reasons why elections might be postponed to provide a richer understanding of why elections do not take place. Many of these occasions, those that we refer to as 'cancelled' elections do equate to more blatant power grabs. Rulers might also use political pressure to annul elections where their outcomes are not in their favour. In many cases, however, elections might be delayed for other reasons. There might be a need to put democratic reforms in place or for technical issues to be resolved first, for example. The risk of loss of life during natural disasters means that there are also humanitarian reasons for postponing.

The article has argued that the case for postponing elections should be evaluated by democratic concepts of electoral integrity, rather than international laws and practices. The article has set out five dimensions of electoral integrity and considered how they can all be negatively affected by natural disasters. The effects of natural disasters are going to be context-specific, but the article has shown how opportunities for deliberation, contestation and participation will all be affected and electoral management quality will suffer. The postponement paradox is that, however, postponing will break institutional certainty and this may lead to situations of statecraft and partisan scrobbling which could trigger democratic breakdown and trust in the system - especially presidential systems. Those states where trust is embedded into political institutions may be able to weather this storm. Given that trust in politicians and political institutions such as parliaments or the courts has become precarious in established democracies as well as fragile democracies, there are difficult waters to be navigated.

Election postponement may be democratically legitimate in a variety of circumstances, including where there are natural disasters if there is a humanitarian case: i.e. there is a threat to human life and health. This is not to say that political actors will seek partisan advantage in postponement. As this article has noted, these strategies might include pushing to postpone when poll ratings are poor to a later point, or they may seek to permanently cancel elections. But there are also strategic opportunities for a partisan advantage during the emergency. They might reduce opportunities for rivals to campaign during the electoral cycle with 'lockdowns' they while continue to campaign themselves and use state resources. They might redirect emergency relief funds for pork-barrelling or undertake de facto 'voter suppression' by not taking sufficient action to ensure equality of participation. Where the principal factor for the postponement is an attempt to gain partisan postponement, this postponement would fall more closely into the category of a cancelled election, not a humanitarian postponement.

The article has further considered some of the mitigating policies to address the natural disaster. There is no one-size fits all solution because the nature of the natural disaster will vary. Low-tech solutions such as early voting will tend to be universally appropriate for accommodating elections to pandemics. Practices such as postal voting, however, will be more successful where there is prior experience amongst electoral officials, no threat of intimidation and a robust postal service. It may make more of a difference, however, not what decision is made, but how that decision is made. The decision to hold or postpone elections will inevitably have proponents and opponents. If options are openly discussed and all major stakeholders are able to contribute to it, then controversies and blockades can be reduced. This is to say that the option chosen may be less critical than the transparency and inclusivity of the process in which decision was made. 
Bibliography

Abney, F Glenn, and Larry B Hill. 1966. "Natural disasters as a political variable: The effect of a hurricane on an urban election." American Political Science Review, 60, (4), p. 974-81. ACE. 2020. Death or Withdrawal of Candidate. aceproject.org/main/english/po/pof07.htm. al-Jazaeri, Ruaa. 2020. "Decrease in participation in People's Assembly elections due to coronavirus, presence of Syrians abroad." In.

Al-Saggaf, Yeslam, and Peter Simmons. 2015. "Social media in Saudi Arabia: Exploring its use during two natural disasters." Technological Forecasting and Social Change, 95, p. 3-15. Al Jazeera. 2020. "Iran announces lowest voter turnout since 1979." Al Jazeera,, 23 February 2020. https://www.aljazeera.com/news/2020/02/iran-announces-lowest-voter-turnout1979-200223135348311.html.

Alarcon, Benigno, and Juan Manuel Trak. 2019. " Venezuela (2013-2018): using timing and sequencing of elections to de-democratize." In Timing and Sequencing of Transitional Elections: Case studies edited by Sead Alihodžić, Nicholas Matatu and Alexandre Raffoul. Stockholm: International IDEA.

Alihodžić, Sead, and Nicholas Matatu. 2019. Timing and Sequencing of Transitional Elections. Stockholm: International IDEA.

Beetham, David. 1994. "Key Principles and Indicies for a Democratic Audit." In Defining Democracy, edited by David Beetham, 25-43. London: Sage.

Beetham, David, Edzia Carvalho, Todd Landman, and Stuart Weir. 2008. Assessing the Quality of Democracy: A practical guide. Stockholm: International IDEA.

Birch, Sarah. 2011. Electoral Malpractice. Oxford: Oxford University Press.

Birch, Sarah, Ursula Daxecker, and Kristine Höglund. 2020. "Electoral violence: An introduction." Journal of Peace Research, p. 0022343319889657.

Birch, Sarah, and David Muchlinski. 2018. "Electoral Violence: patterns and trends." In Electoral Integrity and Political Regimes: Actors, Strategies and Consequences, edited by Holly Ann Garnett and Margarita Zavadskaya, 100-12. Abingdon and New York: Routledge. Bodet, Marc André, Melanee Thomas, and Charles Tessier. 2016. "Come hell or high water: An investigation of the effects of a natural disaster on a local election." Electoral Studies, 43, p. 85-94.

Bovan, Kosta, Benjamin Banai, and Irena Pavela Banai. 2018. "Do natural disasters affect voting behavior? Evidence from Croatian floods." PLoS currents, 10, p.

Brady, Henry E. 2004. "Postponing the California Recall to Protect Voting Rights." PS: Political Science \& Politics, 37, (1), p. 27-32.

Burden, Barry C, and Jeffrey Milyo. 2015. "The Quantities and Qualities of Poll Workers."

Election Law Journal, 14, (1), p. 38-46.

Burke, Jason. 2017. "Kenyan election annulled after result called before votes counted, says court." Guardian, 20th September 2017.

https://www.theguardian.com/world/2017/sep/20/kenyan-election-rerun-not-transparentsupreme-court.

- - . 2020. "Burundi ruling party candidate wins election amid rigging claims." Guardian, 25 May 2020. https://www.theguardian.com/world/2020/may/25/burundi-ruling-partycandidate-wins-election-since-1993.

CBS Chicago. 2020. Primary Election Day Amid Coronavirus Means Shortage Of Poll Workers, Supplies. CBS Chicago,, https://chicago.cbslocal.com/2020/03/17/primary-election-dayamid-coronavirus-means-shortage-of-poll-workers/.

Chen, Jowei. 2013. "Voter Partisanship and the Effect of Distributive Spending on Political Participation." American Journal of Political Science, 57, (1), p. 200-17. 
Clark, Alistair. 2017. "Identifying the determinants of electoral integrity and administration in advanced democracies: the case of Britain." European Political Science Review, 9, (03), p. 471-92.

- - . 2020. It was right to delay England's local elections, but we must consider the wider impact of Covid-19 on electoral administration. Democratic Audit.

Clark, Alistair, and Toby S. James. 2017. "Poll Workers." In Election Watchdogs, edited by Pippa Norris and Alessandro Nai. New York: Oxford University Press.

Cole, Shawn, Andrew Healy, and Eric Werker. 2012. "Do voters demand responsive governments? Evidence from Indian disaster relief." Journal of Development Economics, 97, (2), p. 167-81.

Collier, David, Jody Laporte, and Jason Seawright. 2008. "Typologies: Forming Concepts and Creating Categorical Variables." In Oxford Handbook of Political Methodology, edited by Janet M. Box-Steffensmeier, Henry E. Brady and David Collier. Oxford: Oxford University Press.

Corasaniti, Nick, and Stephanie Saul. 2020. "6 States Have Postponed Primaries During the Pandemic. Here's a List." New York Times, 27 May 2020.

CRED. 2020. General Classification. https://www.emdat.be/classification.

Dahl, R. 1971. Polyarchy: Participation and Opposition. New Haven: Yale University Press. Devereux, Stephen. 2009. "Why does famine persist in Africa?". Food security, 1, (1), p. 25. Electoral Commission. 2019. Administering the poll: UK Parliamentary general election and local government elections in England: guidance for (Acting) Returning Officers. London: Electoral Commission.

Elklit, Jørgen, and Michael Maley. 2019. "Why Ballot Secrecy Still Matters." Journal of Democracy, 30, (3), p. 61-75.

Ellena, Katherine, and Erica Shein. 2020. Emergency Powers and the COVID-19 Pandemic: Protecting Democratic Guardrails.

Fishkin, James S. 2011. When the people speak: Deliberative democracy and public consultation: Oxford University Press.

Flores, Alejandro Quiroz, and Alastair Smith. 2013. "Leader survival and natural disasters." British Journal of Political Science, 43, (4), p. 821-43.

Fofana, Kabinet, and Joschka Philipps. 2020. "Guinea's elections had a clear winner. But its contest for power isn't over." African Arguments, 16 April 2020.

https://africanarguments.org/2020/04/16/guinea-elections-clear-winner-contest-for-powerisnt-over/.

Fraga, Bernard L. 2018. The Turnout Gap: Race, Ethnicity, and Political Inequality in a Diversifying America. Cambridge University Press.

Gallego, Jorge. 2018. "Natural disasters and clientelism: The case of floods and landslides in Colombia." Electoral Studies, 55, p. 73-88.

Garnett, Holly Ann, and Toby S. James. 2020. "Cyber Elections in the Digital Age: Threats and opportunities of technology for electoral integrity." Election Law Journal, p.

Gasper, John T, and Andrew Reeves. 2011. "Make it rain? Retrospection and the attentive electorate in the context of natural disasters." American Journal of Political Science, 55, (2), p. 340-55.

Grynbaum, Michael M. 2020. "No Audience? No Problem. A TV Debate Like Few Others Gets High Marks." New York Times, 16 March 2020.

https://www.nytimes.com/2020/03/16/us/elections/no-audience-cnn-democraticdebate.html.

Gutmann, Amy, and Dennis F Thompson. 2009. Why deliberative democracy? Princeton and Oxford: Princeton University Press. 
Hadziabdic, Irena. 2019. "Transitional elections in Bosnia and Herzegovina, 1996-2002." In Timing and Sequencing of Transitional Elections: Case studies edited by Sead Alihodžić, Nicholas Matatu and Alexandre Raffoul. Stockholm: International IDEA.

Hartmann, Christof. 2015. "Expatriates as voters? The new dynamics of external voting in Sub-Saharan Africa." Democratization, 22, (5), p. 906-26.

Hill, Eleanor, Maria Sobolewska, Stuart Wilks-Heeg, and Magda Borkowska. 2017.

"Explaining electoral fraud in an advanced democracy: Fraud vulnerabilities, opportunities and facilitating mechanisms in British elections." The British Journal of Politics and International Relations, 19, (4), p. 772-89.

Höglund, Kristine. 2009. "Electoral violence in conflict-ridden societies: concepts, causes, and consequences." Terrorism and Political Violence, 21, (3), p. 412-27.

Holland, Kitty. 2020. "Election 2020: Tipperary vote postponed after candidate dies." The Irish Times, 3 February 2020. https://www.irishtimes.com/news/politics/election-2020-

tipperary-vote-postponed-after-candidate-dies-1.4160576.

Horowitz, Juliana, Ruth Igielnik, and Tanya Arditi. 2020. Most Americans Say Coronavirus

Outbreak Has Impacted Their Lives. Washington D.C.: Pew.

Htun, Mala, and G. Bingham Powell. 2013. "Between Science and Engineering: Reflections on the APSA Presidential Task Force on Political Science, Electoral Rules, and Democratic Governance." Perspectives on Politics, 11, (03), p. 808-10.

Hyde, Susan D., and Nikolay Marinov. 2012. "Which Elections Can Be Lost?". Political Analysis, 20, (2), p. 191-210.

Ibrahim, Arwa. 2020. "Syria votes for new parliament amid war, economic woes." Al Jazeera, 19 July 2020. https://www.aljazeera.com/news/2020/07/syria-launches-parliamentaryelections-war-economic-woes-200718174903833.html.

International IDEA. 2019. The Global State of Democracy 2019. Stockholm: International IDEA.

- - . 2020a. Global overview of COVID-19: Impact on elections.

https://www.idea.int/news-media/multimedia-reports/global-overview-covid-19-impactelections.

-- - 2020b. Voter Turnout Database. Stockholm: International IDEA.

James, Toby S. 2011. "Fewer 'costs,' more votes? UK Innovations in Electoral Administration 2000-2007 and their effect on voter turnout." Election Law Journal, 10, (1), p. 37-52.

- - . 2019. "Better Workers, Better Elections? The Workforces of Electoral Management Bodies and Electoral Integrity." International Political Science Review, 40, (3), p. 370-90.

- - . 2020. Comparative Electoral Management: Performance, Networks and Instruments. London and New York: Routledge.

James, Toby S., and Holly Ann Garnett. 2020. "Introduction: the case for inclusive voting practices." Policy Studies, 41, (2-3), p. 113-30.

Johnson, April A., and Sierra Powell. 2020. "Disability and election administration in the United States: barriers and improvements." Policy Studies, 41, (2-3), p. 249-70.

Kelley, Judith. 2011. Data on International Election Monitoring: Three Global Datasets on Election Quality, Election Events and International Election Observation: Inter-University Consortium for Political and Social Research.

Killer, Christian, and Burkhard Stiller. 2019. The Swiss Postal Voting Process and its System and Security Analysis. Paper presented at the International Joint Conference on Electronic Voting.

Koch, Insa. 2017. "When politicians fail: Zombie democracy and the anthropology of actually existing politics." The Sociological Review, 65, (1_suppl), p. 105-20.

Krimmer, Robert, David Duenas-Cid, and Iuliia Krivonosova. 2020. "Debate: safeguarding democracy during pandemics. Social distancing, postal, or internet voting-the good, the bad or the ugly?". Public Money \& Management, p. 1-3. 
Lacey, Marc, and Elisabeth Malkin. 2009. "Flu Is Injecting Itself into Mexican Politics." New York Times, 7 May 2009.

Levitsky, Steven, and Daniel Ziblatt. 2018. How democracies die. New York: Penguin. Loeber, Leontine. 2020. "The use of technology in the election process: who governs?". Election Law Journal, p.

Lydall, Ross. 2020. "Rory Stewart quits race to become London Mayor saying coronavirus crisis made it 'impossible' to campaign " Evening Standard, 6 May 2020.

Machel, Yanick. 2019. "Mozambique Warns of More Flooding from Cyclone-Filled Dams." ReliefWeb, 25 March 2019.

Manafe, DIna, and Nur Yasmin. 2019. "What Kills Indonesian Election Officials?" Jakarta Globe, 13 May 2019. https://jakartaglobe.id/context/what-kills-indonesian-election-officials. Mansbridge, Jane J., and John Parkinson. 2012. Deliberative Systems : Deliberative Democracy at the Large Scale, Theories of Institutional Design. Cambridge: Cambridge University Press.

Mark, Monica. 2014. "Liberia suspends elections due to Ebola outbreak." Guardian, 9 October 2014.

McDonald, Michael P. 2020. United States Voting Project: 2020 Presidential Nomination Contest Turnout Rates. www.electproject.org/2020p.

Mckenzie, David, Brent Swails, and Smith-Spark. 2019. "Nigerian parties condemn lastminute election delay." CNN, 16 February 2019.

https://edition.cnn.com/2019/02/15/africa/nigeria-elections-delayed/index.html.

Momtaz, Rym , Elisa Braun, and Laura Kayali. 2020. "Coronavirus pushes French local election turnout to historic low." Politico, 15 March 2020.

https://www.politico.eu/article/coronavirus-pushes-french-local-election-turnout-tohistoric-low/.

Morley, Michael T. 2017. "Election Emergencies: Voting in the Wake of Natural Disasters and Terrorist Attacks." Emory LJ, 67, p. 545.

NDTV. 2020. "Amit Shah's Virtual Rally Amid Coronavirus Pandemic Insult To Bihar: Congress " NDTV, 7 June 2020. https://www.ndtv.com/india-news/amit-shahs-virtual-rally-amidcoronavirus-pandemic-an-insult-to-bihar-congress-2242322.

New York Times. 2020. The New York Times Coronavirus (Covid-19) Cases and Deaths in the United States https://data.humdata.org/dataset/nyt-covid-19-data.

Norris, Pippa. 2014. Why Electoral Integrity Matters. New York: Cambridge University Press. -- - 2015. Why Elections Fail. New York: Cambridge University Press.

Norris, Pippa, and Andrea Abel van Es. 2016. Checkbook Elections?: Political Finance in Comparative Perspective: Oxford University Press.

Norris, Pippa, Thomas Wynter, and Sarah Cameron. 2018. Perceptions of Electoral Integrity, (PEI-6.0).

OSCE/OHDIR. 2016. Election Observation Mission FYR Macedonia Early Parliamentary Elections Scheduled for 5 June 2016. Warsaw: OSCE.

-- - 2020. Opinion On The Draft Act On Special Rules For Conducting The General Election Of The President Of The Republic Of Poland Ordered In 2020 (Senate Paper No. 99. Warsaw: OSCE/OHDIR.

Pawson, Ray, Trisha Greenhalgh, Gill Harvey, and Kieran Walshe. 2005. "Realist review - a new method of systematic review designed for complex policy interventions." Journal of Health Services Research \& Policy, 10, (1_suppl), p. 21-34.

Persily, Nathaniel, and Charles Stewart III. 2020. 'Ten Recommendations to Ensure a Healthy and Trustworthy 2020 Election '. Lawfare. https://www.lawfareblog.com/ten-

recommendations-ensure-healthy-and-trustworthy-2020-election. 
Pokharel, Bhojraj, and Shrishti Rana. 2019. "Nepal's 2008 Constituent Assembly elections." In Timing and Sequencing of Transitional Elections, edited by Sead Alihodžić, Nicholas Matatu and Alexandre Raffoul, 97-106.

Przeworski, Adam. 1999. "Minimalist Conception of Democracy: A Defence." In Democracy's Value, edited by lan Shapiro and Casiano Hacker-Cordon. Cambridge: Cambridge University Press. [Reprinted in Robert A. Dahl et al (eds) The Democracy Sourcebook].

PTI. 2020. "After virtual rally, BJP to connect personally with people in Bihar." The Week, 10 June 2020. https://www.theweek.in/news/india/2020/06/10/after-virtual-rally-bjp-toconnect-personally-with-people-in-bihar.html.

Public Health England. 2020a. Beyond the data: Understanding the impact of COVID-19 on BAME groups. London: Public Health England.

- - . 2020b. Disparities in the risk and outcomes of COVID-19. London: Public Health England.

Rallings, Colin, and Michael Thrasher. 1997. Local Elections in Britain. London: Routledge. Reilly, Benjamin. 2002. "Elections in post-conflict scenarios: Constraints and dangers." International Peacekeeping, 9, (2), p. 118-39.

Reuters. 2020. "Citing Ballot Tampering, Malawi Court Voids Presidential Election "New York Times, 3 February 2020. https://www.nytimes.com/2020/02/03/world/africa/Malawipresident-election-fraud.html.

RNZ. 2019. "Local elections postponed in volcano-affected areas of PNG." Radio New Zealand, 2 July 2019.

Saleh, Yasmine. 2013. "Egypt cancels parliamentary vote dates after court ruling." Reuters, 7th March 2020. https://www.reuters.com/article/us-egypt-elections-dates/egypt-cancelsparliamentary-vote-dates-after-court-ruling-idUSBRE92616620130307.

Schneider, Paige, and David Carroll. 2020. "Conceptualizing more inclusive elections: violence against women in elections and gendered electoral violence." Policy Studies, 41, (23), p. 172-89.

Schumaker, Erin. 2020. "Timeline: How coronavirus got started." ABC News, 23 April 2020. https://abcnews.go.com/Health/timeline-coronavirus-started/story?id=69435165.

Schwarz, Franziska. 2020. "Kommunalwahl in Bayern: Stichwahl am 29. März läuft anders ab als sonst." Merku.de, 29th March 2020. https://www.merkur.de/politik/stichwahlkommunalwahl-2020-bayern-termin-ablauf-briefwahl-losentscheid-zr-13442878.html.

Sen, Amartya. 1999a. Development as freedom. Oxford: Oxford University Press.

Sen, Amartya Kumar. 1999b. "Democracy as a universal value." Journal of Democracy, 10, (3), p. 3-17.

Sinclair, Betsy, Thad E Hall, and R Michael Alvarez. 2011. "Flooding the vote: Hurricane Katrina and voter participation in New Orleans." American Politics Research, 39, (5), p. 92157.

Smith, Alastair. 2004. Election timing: Cambridge University Press.

Spinelli, Antonio. 2020. Managing Elections under the COVID-19 Pandemic The Republic of Korea's Crucial Test. Stockholm: International IDEA.

Sreedharan, CHINDU, Einar Thorsen, and NIRJANA Sharma. 2019. "Disaster Journalism: Building Media Resilience in Nepal." In.: Bournemouth University in association with UNESCO Kathmandu.

Stein, Robert M. 2015. "Election administration during natural disasters and emergencies: Hurricane Sandy and the 2012 election." Election Law Journal, 14, (1), p. 66-73.

Strzelecki, Marek. 2020. "Virus Crisis Boosts Polish President Before Vote Under Lockdown." Bloomberg, 22 March 2020. https://www.bloomberg.com/news/articles/2020-03-22/viruscrisis-boosts-president-before-vote-in-locked-down-poland.

Supreme Court of Wisconsin. 2020. "Wisconsin Legislature v. Evers. No. 2020AP608-OA " In.: Supreme Court of Wisconsin,. 
Thanawala, Sudhin. 2020. "Poor Planning First and Foremost.' Poll Workers Describe Chaos During Georgia Primaries." Time, 12 June 2020. https://time.com/5853115/poll-workerschaos-georgia-primaries/.

Tribune. 2020. "Photo of villagers listening to Amit Shah's rally on LED screen unleashes Twitter storm." The Trubine, 11 June 2020.

https://www.tribuneindia.com/news/nation/photo-of-villagers-listening-to-amit-shahs-rallyon-led-screen-unleashes-twitter-storm-97655.

UN General Assembly. 1948. The Universal Declaration of Human Rights: UN General Assembly.

Venice Commission. 2002. Code of Good Practice in Electoral Matters: Guidelines and Explanatory report. Strasbourg: Venice Commission.

Vickery, Chad, David Ennis, and Katherine Ellena. 2018. When Are Elections Good Enough? Validating or Annulling Election Results. Washington D.C.: IFES.

Vladisavljevic, Anja, Samir Kajosevic, Milica Stojanovic, and Sinisa Jakov Marusic. 2020.

"Elections Return to Balkan Agenda as Pandemic Wanes." 5 May 2020.

Vonnahme, Greg, and Beth Miller. 2013. "Candidate cues and voter confidence in American elections." Journal of Elections, Public Opinion \& Parties, 23, (2), p. 223-39.

WHO. 2019. "Coronavirus disease 2019 (COVID-19) Situation Report - 51." World Health Organisation, 11 March 2020.

- - . 2020a. WHO Coronavirus Disease (COVID-19) Dashboard. https://covid19.who.int/.

- - . 2020b. "WHO Director-General's opening remarks at the media briefing on COVID-19

- 11 March 2020." World Health Organisation, 11 March 2020.

Wilks-Heeg, Stuart. 2008. Purity of Elections in the UK: Causes for Concern. York: Joseph Rowntree Trust.

Xinhua. 2020. "Mongolian president proposes to postpone parliamentary elections." Xinhua, 26th March 2020. http://www.xinhuanet.com/english/2020-03/26/c 138916868.htm.

Zengerle, Patricia, and Joseph Guyler Delva. 2010. "Haitian president says February 28 elections postponed." Reuters, 27 January 2010.

Zoltán, Kovács. 2020. "Hungary's Coronavirus Bill - Orbán's bid for absolute power? ." Index.hu, 30 March 2020.

https://index.hu/english/2020/03/24/hungary coronavirus bill viktor orban fidesz sweep ing powers indefinite term/. 